Bài báo khoa học

\title{
Nghiên cứu phân bố front nhiệt độ nước biển tầng mặt ở biển Việt Nam phục vụ dụ̣ báo ngư trường khai thác hải sản
}

\author{
Nguyễn Văn Hướng ${ }^{*}$, Nguyễn Hoàng Minh ${ }^{1}$, Bùi Thanh Hùng ${ }^{1}$, Trần Văn Vụ ${ }^{1}$, Cấn Thu \\ Văn² \\ ${ }^{1}$ Viện Nghiên cứu Hải sản; nvhuong0509@gmail.com; nhminh10@gmail.com; \\ bthungrimf@gmail.com; vurimf@gmail.com \\ ${ }^{2}$ Trường Đại học Tài nguyên và Môi trường TP.HCM; ctvan@hcmunre.edu.vn \\ * Tác giả liên hệ: nvhuong0509@gmail.com; Tel: +84-0982513247
}

Ban Biên tập nhận bài: 15/9/2020; Ngày phản biện xong: 27/10/2020; Ngày đăng bài: $25 / 11 / 2020$

Tóm tắt: Sự xuất hiện của các dải front nhiệt ở biển Việt Nam phụ thuộc vào sự hoạt động của hệ thống gió mùa đông bắc và tây nam. Trong mùa gió đông bắc, ở vịnh Bắc Bộ tồn tại dải front gần như chạy song song với đường đẳng sâu $50 \mathrm{~m}$, mạnh nhất ở khu vực gần Bạch Long Vĩ và phía bắc Đèo Ngang, gradient nhiệt bề mặt tại khu vực này $\geq 0,2^{\circ} \mathrm{C} / 10 \mathrm{~km}$. Ở vùng biển Nam Trung Bộ tổn tại một dải front nằm ở ngoài khơi Trung Bộ dọc theo kinh tuyến $110,0^{\circ} \mathrm{E}$ từ khu vực biển Đà Nẵng đến đảo Phú Quý và ở khu vực cửa vịnh Thái Lan hình thành một dải front ở gần khu vực ngoài khơi vùng biển Cà Mau. Mùa gió tây nam, ở khu vực ngoại vi trung tâm hoạt động nước trồi Nam Trung Bộ tồn tại một dải front kéo dài từ phía bắc Vũng Tàu đến Khánh Hòa với gradien ngang của nhiệt độ và độ muối rất lớn. Bên cạnh đó, ở khu vực phía bắc tâm hoạt động nước trồi ngoài khơi Đèo Ngang-Quảng Bình là dải chồng lấn của khối nước nhạt lợ $\left(\mathrm{T}=28,0-31,0^{\circ} \mathrm{C}, \mathrm{S}<33,0 \%\right.$ ) khu vực ven bờ tây Vịnh Bắc Bộ và khối nước ngoài khơi có nhiệt độ thấp, độ muối tương đối cao $\left(\mathrm{T}=27,0-28,0^{\circ} \mathrm{C}, \mathrm{S}=33,0-34,0 \%\right.$ o). Kết quả nghiên cứu ngư trường khai thác cá cho thấy, khu vực có sản lượng cá khai thác cao thường tập trung ở khu vực gần các dải fornt này hoặc gần khu vực có gradien nhiệt độ $\geq 0,05 \% 10 \mathrm{~km}$ ở các vùng biển vịnh Bắc Bộ, Nam Trung Bộ và Tây Nam Bộ.

Từ khóa: front, gradien nhiệt độ, ngư trường khai thác hải sản.

\section{Mở đầu}

Front đại dương là những dải tương đối hẹp ngăn cách những vùng không gian rộng của các khối nước khác nhau hay các khu vực có cấu trúc thẳng đứng khác nhau. Các front hầu như luôn đi kèm với sự tăng cường gradient ngang của các yếu tố như: nhiệt độ, độ muối, mật độ, chất dinh dưỡng và các đặc trưng khác [1-5]. Nhiều kết quả nghiên cứu trên thế giới cũng như ở Việt Nam đã chỉ ra rằng, các bãi cá tập trung ở gần khu vực có sự xâm nhập của nước tầng sâu giàu dinh dưỡng nhất là những khu vực có dải front nhiệt muối giữa các khối nước với những đặc trưng lý hóa khác nhau [3, 4, 6, 7]. Việc nghiên cứu về front nhiệt độ nước biển đã được thực hiện ở nhiều nước trên thế giới và có nhiều công trình được công bố trong đó có cả những nghiên cứu ở Biển Đông $[1,2,7-10]$. Ở Việt Nam, nghiên cứu về front vẫn còn chưa nhiều, công trình nghiên cứu của đề tài KT03-10 năm 1995 là công trình nghiên cứu mô tả rõ nhất về fornt ở biển Việt Nam [7]. Nhưng kết quả nghiên cứu chưa trình bày rõ phân bố về front theo tháng trong năm do nguồn số liệu chưa đủ. Vì vậy, để phục vụ dự báo ngư trường khai thác hải sản quy mô hạn ngắn cần thiết phải nghiên cứu tính toán chi tiết hơn đối với sự phân bố của front theo từng tháng hoặc thậm chí hạn ngắn hơn nữa. Từ đó có thể dự báo được các ngư trường tiềm năng tập trung nguồn lợi hải sản cao phục vụ khai thác hải sản của ngư dân tốt hơn. Bài viết trình bày kết 
quả phân tích xác định front nhiệt độ ở vùng biển Việt Nam và lân cận dựa vào nguồn số liệu hải dương được thu thập, tổng hợp theo trung bình tháng từ năm 2014-2018 góp phần vào cơ sở khoa học dự báo ngư trường khai thác hải sản hiện nay.

\section{Tài liệu và phương pháp nghiên cứu}

\subsection{Khu vục nghiên cứu}

Khu vực nghiên cứu là vùng biển Việt Nam và lân cận (Hình 1). Việt Nam có vùng biển rộng lớn với diện tích trên 1 triệu $\mathrm{km}^{2}$, đường bờ biển dài khoảng $3.260 \mathrm{~km}$ với hơn 3.000 hòn đảo lớn nhỏ nằm dọc chiều dài bờ biển từ Bắc đến Nam. Đến nay, ở vùng biển này đã phát hiện được chừng 12.000 loài sinh vật $(6.000$ loài động vật đáy; 2.435 loài cá với trên 100 loài có giá trị kinh tế; 653 loài rong biển; 657 loài động vật phù du; 537 loài thực vật phù du; 94 loài thực vật ngập mặn; 225 loài tôm biển; 14 loài cỏ biển; 15 loài rắn biển; 12 loài thú biển; 5 loài rùa biển và 43 loài chim nước). Nguồn lợi hải sản biển Việt Nam có vị trí quan trọng và còn nhiều tiềm năng trong nền kinh tế quốc dân. Kết quả điều tra giai đoạn 20112015 cho thấy, tổng trữ lượng các nhóm cá biển, giáp xác và động vật chân đầu là 4,36 triệu tấn (dao động trong khoảng 4,1-4,6 triệu tấn) và khả năng khai thác bền vững là là 1,81 triệu tấn bao gồm: gồm 1,06 triệu tấn cá nổi nhỏ; 412 ngàn tấn cá nổi xa bờ và 338 ngàn tấn

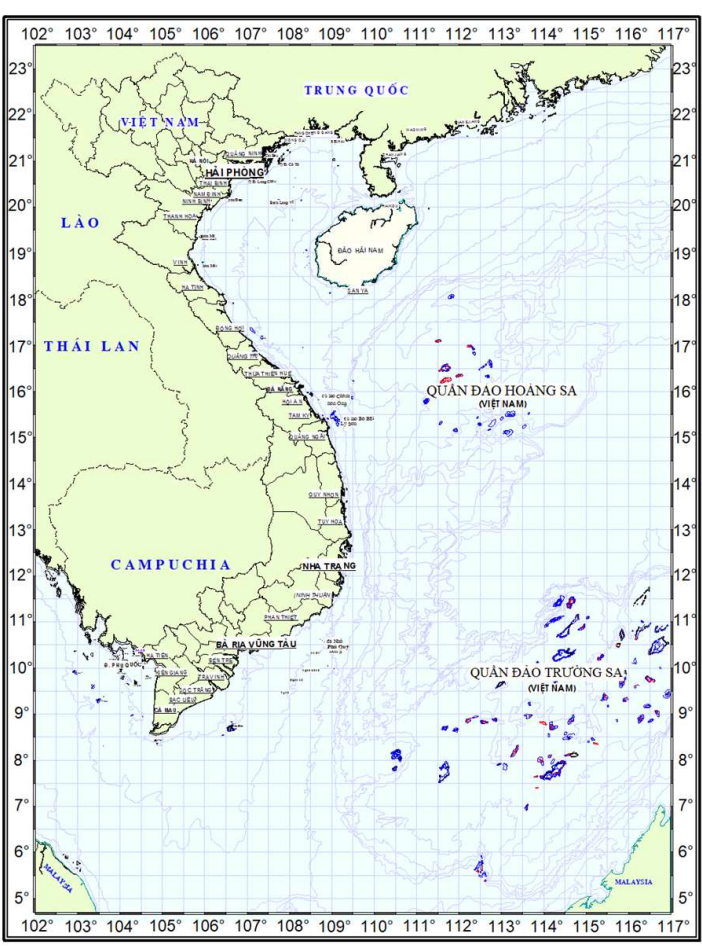

Hình 1. Vùng biển Việt Nam và lân cận. hải sản tầng đáy $[11,12]$.

\subsection{Nguồn số liệu}

Dữ liệu nhiệt độ nước biển được lấy từ cơ sở dưc liệu (CSDL) hải dương học-là CSLD tổng hợp các yếu tố khí tượng thuỷ văn hải dương trong các năm từ 2014-2018 và nguồn số liệu 3D nhiệt độ trung bình tháng trong các năm từ 2014-2018 thuộc dự án movimar với độ phân giải $0,5 \times 0,5$ độ kinh vĩ.

Dữ liệu nghề cá được lấy từ CSDL sổ nhật kí khai thác nghề lưới rê, vây và chụp mực các tỉnh ven biển từ 1/2017-12/2018 đây là thời gian nguồn số liệu nghề cá được thu thập, cập nhật nhật hàng tháng (số liệu liên tục 12 tháng trong năm) về vị trí (tọa độ), thời gian khai thác, thành phần loài, sản lượng khai thác...thông qua các Chi cục Khai thác và Bảo vệ Nguồn lợi Thủy sản ở 10 tỉnh thành ven biển (Hải Phòng, Nam Định, Thanh Hóa, Nghệ An, Bình Định, Ninh Thuận, Bình Thuận, Vũng Tàu, Cà Mau và Kiên Giang) được lưu trữ tại Viện nghiên cứu Hải sản.

\subsection{Phưong pháp nghiên cứu}

Phưong pháp tính toán xác định front: Tính toán gradient nhiệt (sự biến đổi của nhiệt độ) theo phương ngang trên tám hướng là hướng Bắc, Đông Bắc, Đông, Đông Nam, Nam, Tây Nam, Tây, Tây Bắc tại mỗi ô lưới $0,5 \times 0,5$ độ kinh vĩ. Giá trị lớn nhất trong các giá trị tính theo 8 hướng đó là giá trị gradient theo phương ngang của nhiệt độ. Dải front được xác định là khu vực có gradient $\mathrm{T} \geq 0,1^{\circ} \mathrm{C} / 10 \mathrm{~km}$.

Phương pháp vẽ so đồ: Úng dụng kĩ thuật GIS, xây dựng lớp thông tin về phân bố gradient nhiệt độ nước biển tầng mặt và tổng sản lượng khai thác cá theo thời gian tháng và hai mùa gió 
đông bắc, tây nam. Phân tích không gian xác định khu vực xuất hiện front trên toàn bộ vùng biển nghiên cứu.

\section{Kết quả nghiên cứu và thảo luận}

\section{1. Đặc điểm phân bố và biến động của front nhiệt ở biển Việt Nam và lân cận}

Nhiệt độ nước biển tầng mặt ở vùng biển Việt nam và lân cận dao động trong khoảng $15,7-$ $31,1^{\circ} \mathrm{C}$. Nhiệt độ nước biển cao nhất ở vùng biển Tây Nam Bộ (trung bình là $28,6^{\circ} \mathrm{C}$ trong mùa gió đông bắc và $29,7^{\circ} \mathrm{C}$ trong mùa gió tây nam) và thấp nhất ở vịnh Bắc Bộ trung bình là 24,1 ${ }^{\circ} \mathrm{C}$ trong mùa gió đông bắc và $28,5^{\circ} \mathrm{C}$ trong mùa gió tây nam. Biên độ dao đông nhiệt độ ở vịnh Bắc Bộ cũng cao nhất so với các vùng biển còn lại ở biển Việt Nam (mùa gió đông bắc là 13,3 ${ }^{\circ} \mathrm{C}$, mùa gió tây nam là $8,1^{\circ} \mathrm{C}$ ). Kết quả tính gradient ngang trung bình thánh nhiệt độ nước biển tầng mặt ở toàn bộ vùng biển nghiên cứu thấy rằng, giá trị gradient nhiệt dao động trong khoảng 0,001 đến $0,89^{\circ} \mathrm{C} / 10 \mathrm{~km}$, trung bình gradient nhiệt cao nhất ở vùng biển vịnh Bắc Bộ trong cả hai mùa gió, đặc biệt là trong mùa gió đông bắc (Bảng 1$)$. Điều này minh chứng rằng, ở khu vực vịnh Bắc Bộ luôn tồn tại các khối nước khác biệt nhau giữa khu vực ven bờ và khu vực ngoài khơi, các đặc trưng lý hóa giữa các khối nước này luôn khác nhau. Dựa vào giá trị gradient nhiệt độ theo phương ngang để xác định được khu vực xuất hiện, phạm vi phân bố dải front nhiệt (khu vực có gradient $\left.\mathrm{T} \geq 0,1^{\circ} \mathrm{C} / 10 \mathrm{~km}\right)$.

Bảng 1. Kết quả thống kê nhiệt độ tầng mặt và giá trị gradient nhiệt độ nước biển tầng mặt theo phương ngang trong mùa gió đông bắc và tây nam ở biển Việt Nam.

\begin{tabular}{|c|c|c|c|c|c|c|c|}
\hline \multirow[t]{2}{*}{ Mùa } & \multirow[t]{2}{*}{ Vùng biển } & \multicolumn{3}{|c|}{ Nhiệt độ tầng mặt $\left({ }^{\circ} \mathrm{C}\right)$} & \multicolumn{3}{|c|}{ Gradient nhiệt tầng mặt $\left({ }^{\circ} \mathrm{C} / 10 \mathrm{~km}\right)$} \\
\hline & & $\begin{array}{l}\text { Nhỏ } \\
\text { nhất } \\
\left({ }^{\circ} \mathrm{C}\right)\end{array}$ & $\begin{array}{l}\text { Lớn } \\
\text { nhất } \\
\left({ }^{\circ} \mathrm{C}\right)\end{array}$ & $\begin{array}{c}\text { Trung } \\
\text { bình } \\
\left({ }^{\circ} \mathrm{C}\right)\end{array}$ & $\begin{array}{l}\text { Nhỏ nhất } \\
\left({ }^{\circ} \mathrm{C} / 10 \mathrm{~km}\right)\end{array}$ & $\begin{array}{l}\text { Lớn nhất } \\
\left({ }^{\circ} \mathrm{C} / 10 \mathrm{~km}\right)\end{array}$ & $\begin{array}{l}\text { Trung bình } \\
\left({ }^{\circ} \mathrm{C} / 10 \mathrm{~km}\right)\end{array}$ \\
\hline \multirow{4}{*}{$\begin{array}{l}\text { Mùa gió } \\
\text { đông bắc }\end{array}$} & Vịnh Bắc Bộ & 15,7 & 29,0 & 24,1 & 0,002 & 0,627 & 0,127 \\
\hline & $\begin{array}{l}\text { Miền Trung và } \\
\text { xa bờ }\end{array}$ & 21,6 & 30,7 & 27,5 & 0,001 & 0,495 & 0,040 \\
\hline & Đông Nam Bộ & 24,5 & 29,7 & 27,6 & 0,002 & 0,204 & 0,035 \\
\hline & Tây Nam Bộ & 26,0 & 30,1 & 28,6 & 0,002 & 0,892 & 0,050 \\
\hline \multirow{4}{*}{$\begin{array}{l}\text { Mùa gió } \\
\text { tây nam }\end{array}$} & Vịnh Bắc Bộ & 22,6 & 30,7 & 28,5 & 0,003 & 0,269 & 0,054 \\
\hline & $\begin{array}{l}\text { Miền Trung và } \\
\text { xa bờ }\end{array}$ & 22,8 & 31,0 & 28,9 & 0,001 & 0,484 & 0,032 \\
\hline & Đông Nam Bộ & 25,8 & 30,8 & 29,1 & 0,001 & 0,350 & 0,028 \\
\hline & Tây Nam Bộ & 27,3 & 31,1 & 29,7 & 0,001 & 0,890 & 0,042 \\
\hline
\end{tabular}

Mùa gió đông bắc: Trên toàn vùng biển Việt Nam xuất hiện 03 dải front chính: 1) ở vịnh Bắc Bộ; 2) Nam Trung Bộ và 3) cửa vịnh Thái Lan (Hình 2), cụ thể: 

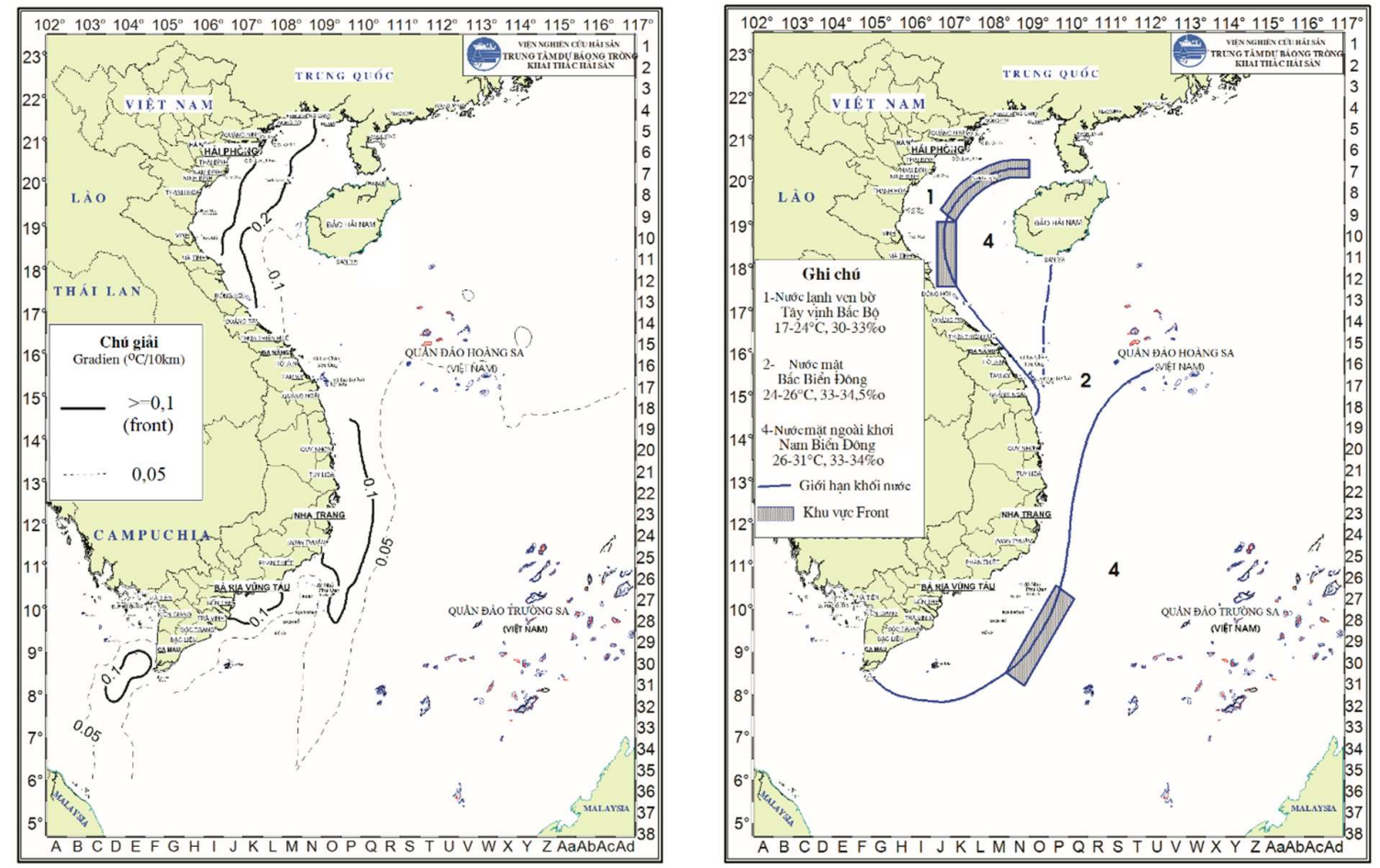

Hình 2. Phân bố front nhiệt (gradient $=0,1{ }^{\circ} \mathrm{C} / 10 \mathrm{~km}$ ) theo tính toán (bên phải), Kết quả đề tài $\mathrm{KT} 03-10$ (bên trái) trong mùa gió đông bắc, biển Việt Nam.

+ Dải front chính Vịnh Bắc Bộ: là giới hạn giữa khối nước lạnh, nhạt từ tây bắc vịnh tràn xuống và khối nước trung tâm vịnh có nhiệt độ và độ muối tương đối cao. Dải front này gần như chạy song song với đường đẳng sâu $50 \mathrm{~m}$, mạnh nhất ở khu vực gần Bạch Long Vĩ và phía bắc Đèo Ngang, gradient nhiệt bề mặt tại khu vực này $\geq 0,2^{\circ} \mathrm{C} / 10 \mathrm{~km}$, nơi cao nhất có thể lên tới $0,63{ }^{\circ} \mathrm{C} / 10 \mathrm{~km}$. Ở dải front này gradient độ muối cũng cao, trung bình là $0,12 \% 0 / 10 \mathrm{~km}$. Phía nam vĩ tuyến $17,0^{\circ} \mathrm{N}$ front này chỉ tổn tại trong các tháng đầu mùa đông ở nơi có sự đột biến của độ sâu. Khối nước lạnh và nhạt tràn lển lớp nước tương đối ấm, gradient ngang của nhiệt độ được giữ ở mức cao do quá trình xáo trộn thẳng đứng mạnh tạo nên tầng nước lớn đủ sức giữ ổn định cho nhiệt độ trong từng khối nước. Vào thời kỳ cuối mùa gió đông bắc, khi nhiệt độ nước vùng trung tâm vịnh giảm, các front này cũng bị mờ đi và mất hẳn.

Trong quá trình hình thành và di chuyển về phía nam của khối nước lạnh ven bờ tây bắc vịnh, hình thành các front nhiệt tại khu vực tây bắc Bạch Long Vĩ và phía bắc Đèo Ngang. Trong các bản đồ diễn biến phân bố gradient nhiệt độ trong mùa đông từ tháng 11 năm trước cho đến tháng 4 năm sau thấy rằng, ở vịnh Bắc Bộ dải front phía tây bắc Bạch Long Vĩ tồn tại gần như liên tục (Hình 3).

+ Dải front ở vùng biển Nam Trung Bộ: giữa khối nước lạnh từ bắc Biển Đông được hình thành do dòng chảy từ phia bắc xuống được tăng cường ép sát bờ và khối nước ngoài khơi nam Biển Đông luôn giữ nhiệt độ ổn định trên $27,0^{\circ} \mathrm{C}$ tổn tại một front nằm ở ngoài khơi trung bộ dọc theo kinh tuyến $110,0^{\circ} \mathrm{E}$ từ khu vực biển Đà Nẵng đến Phú Quý. Dải front này được hình thành rõ bắt đầu từ tháng 12 năm trước và phát triển rộng dần cho đến tháng 3 năm sau giảm dần ở tháng 4 , nó tồn tại từ khu vực gần bở ra đến phạm vi $111,0^{\circ} \mathrm{E}$ thì biến mất hoàn toàn.

+ Dái front ở Cứa vịnh Thái Lan: Front này hình thành là do nước lạnh từ trên phía Bắc đi xuống gặp nước nóng hơn trong vịnh Thái Lan tạo thành bắt đầu từ tháng 11 và thể hiện rõ nhất trong các tháng 1 , tháng 2 . Dải front này cũng đã được công bố trong nghiên cứu [1], tác giả đã xác định rõ hơn xu thế biến đổi của trường nhiệt qua các front bằng các mặt cắt ngang.

Tại khu vực front, độ dầy của các khối nước không giống nhau, khối nước từ phía bắc biển khi đi vào thềm lục địa gây xáo trộn mạnh xuống tận đáy. Khối nước ngoài khơi mỏng hơn nên 
lớp nhảy vọt ở đây có thể cắt ngang front. Trong dải ven bờ vùng cửa sông Cửu Long cũng tồn tại một dải front giữa nước nhạt lợ ven bờ và nước từ bắc Biển Đông xuống.
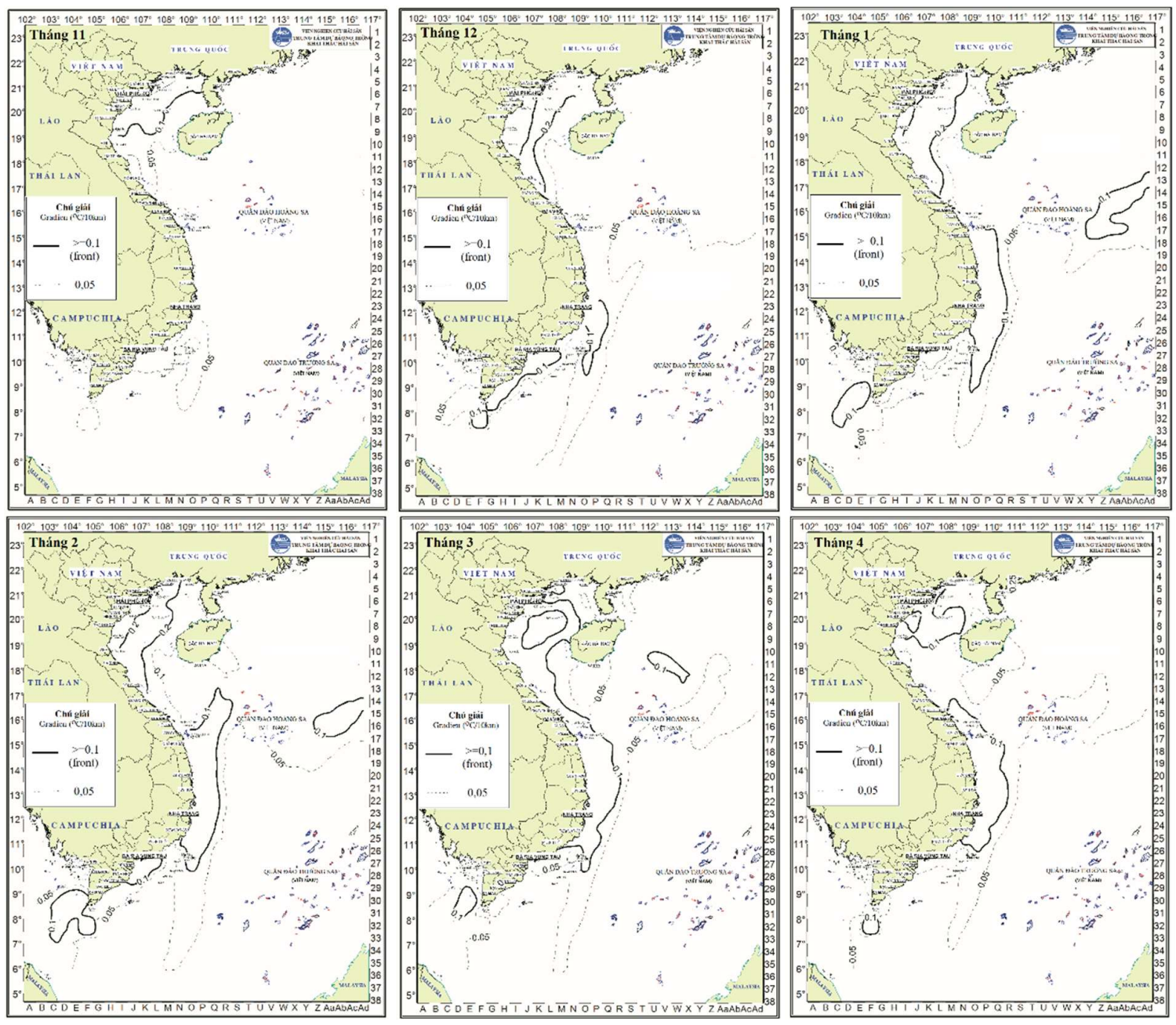

Hình 3. Phân bố front nhiệt (gradient $=0,1^{\circ} \mathrm{C} / 10 \mathrm{~km}$ ) trung bình tháng trong mùa gió đông bắc, biển Việt Nam.

Mùa gió tây nam: Trên toàn vùng biển Việt Nam xuất hiện hai dạng front là front vùng cửa sông ven bờ nơi giao nhau giữa khối nước mặn lợ với nước thềm lục địa và front vùng ngoại vi các trung tâm hoạt động của nước trồi.

Front ngoại vi trung tâm hoạt động nước trồi Nam Trung Bộ là nơi gặp nhau của khối nước từ phía bắc xuống có nhiệt độ thấp, độ muối cao và khối nước từ phía nam đi lên có nhiệt độ cao, độ muối thấp. Dải front này kéo dài từ bắc Vũng Tàu đến Khánh Hòa với đặc điểm là gradient ngang của nhiệt độ rất lớn (ở tâm nước trồi giá trị gradient ngang nhiệt độ $>0,2^{\circ} \mathrm{C} / 10 \mathrm{~km}$ ) (Hình 4). Kết quả nghiên cứu của Tố, 1995 cũng tương tự và đã tính toán được giữa hai khối nước này, chênh lệch nhiệt độ lên tới $4,0{ }^{\circ} \mathrm{C}$ và độ muối $1,5 \%$ [7]. Trong tháng 5 và tháng 6 , dải front này bắt đầu hình thành và thể hiện rõ hơn trong các tháng 7,8 khi mà cường độ và phạm vi của nước trồi đã hoạt động mạnh.

Front thủy văn ngoại vi phía bắc tâm hoạt động nước trồi Đèo Ngang là dải chồng lấn của khối nước nhạt lợ $\left(\mathrm{T}=28,0-31,0^{\circ} \mathrm{C}, \mathrm{S}<33 \%\right.$ ) ven bờ tây vịnh Bắc Bộ chịu ảnh hưởng lớn của nước hệ thống sông miền Bắc (sông Hồng, sông Mã, sông Cả...) và khối nước nhiệt độ thấp, độ muối tương đối cao $\left(\mathrm{T}=27,0-28,0^{\circ} \mathrm{C}, \mathrm{S}=33,0-34,0 \%\right.$ o được hình thành từ nguồn nước tầng sâu Biển Đông xâm nhập lên lớp mặt dưới tác động của ứng suất roto gió mùa tây nam khu vực bất đồng nhất về hướng và cường độ. Giá trị chênh lệch nhiệt độ giữa hai khối nước không lớn như dải front nước trồi Nam Trang Bộ. Trong thời gian tháng 9 , tháng 10 hầu như không thấy xuất hiện rõ các dải front trên toàn bộ Biển Đông (Hình 5). 

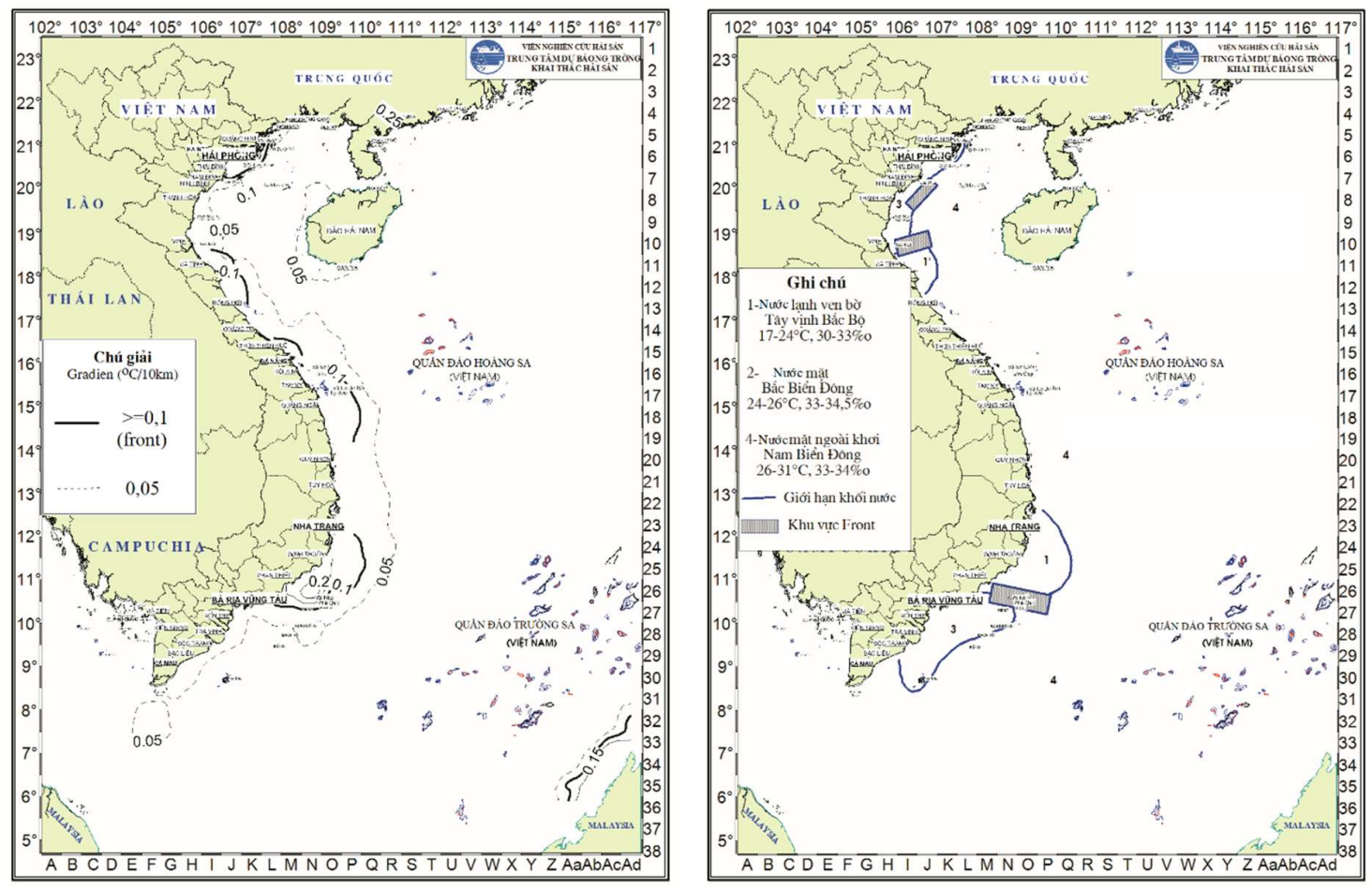

Hình 4. Phân bố front nhiệt (gradient $=0,1^{\circ} \mathrm{C} / 10 \mathrm{~km}$ ) theo tính toán (bên phải), Kết quả đề tài $\mathrm{KT}$ 03-10 (bên trái) trong mùa gió tây nam biển Việt Nam.

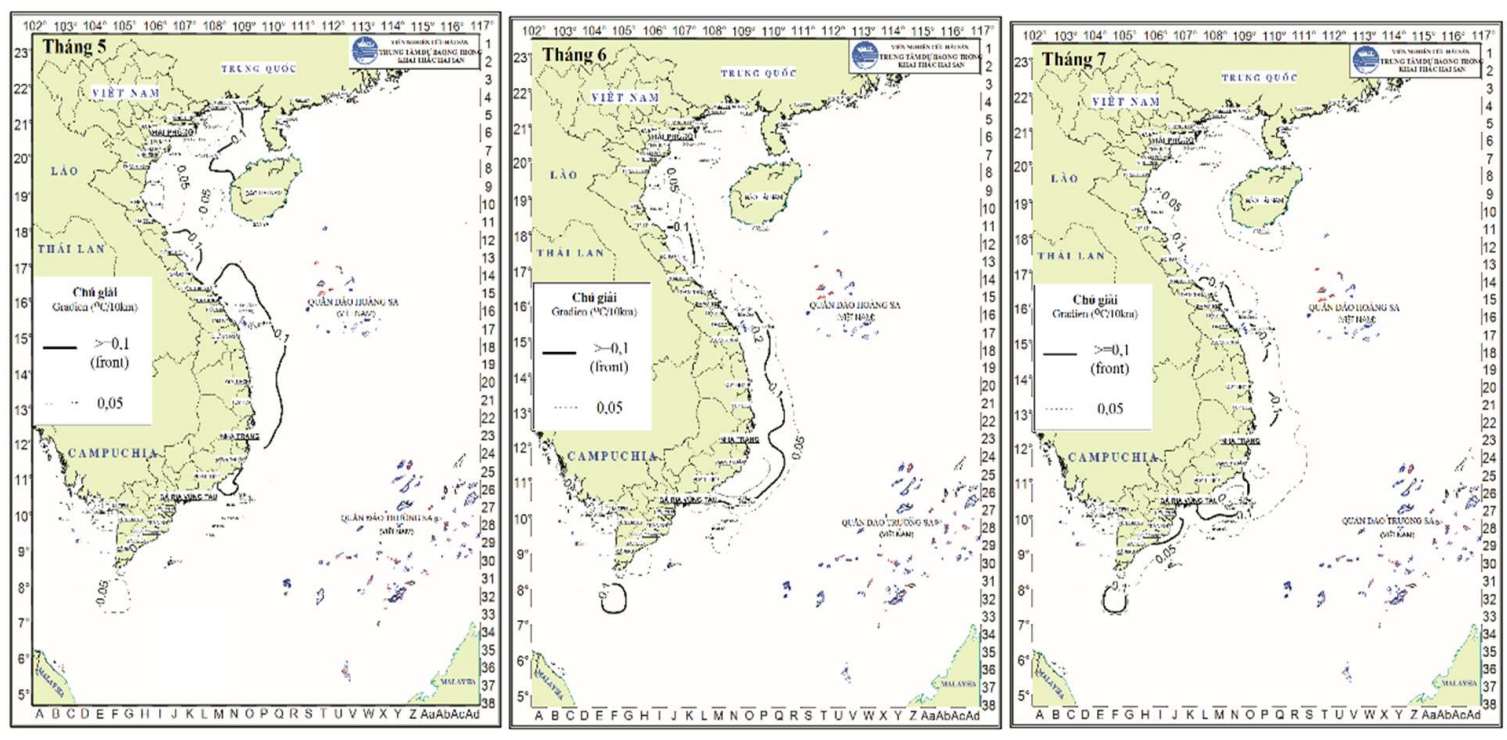



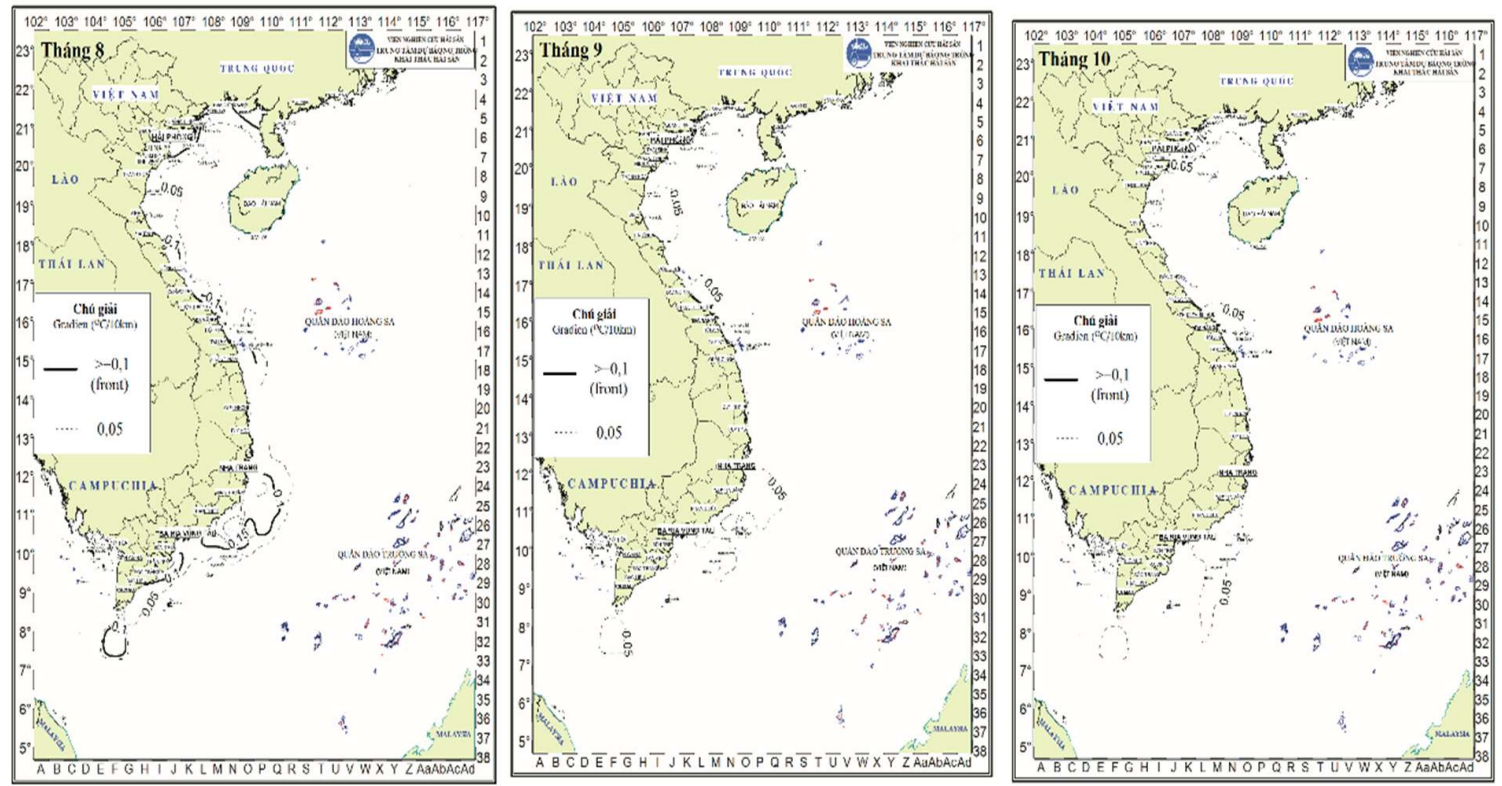

Hình 5. Phân bố front nhiệt (gradient $=0,1^{\circ} \mathrm{C} / 10 \mathrm{~km}$ ) trung bình tháng trong mùa gió đông bắc, biển Việt Nam.

\subsection{Phân bố ngu truờng khai thác hải sản liên quan đến các dải front nhiệt}

Kết quả thống kê tổng sản lượng khai thác cá từ sổ nhật kí khai thác trong giai đoạn 20172018 của 1.650 tàu cá ở các tỉnh ven biển thấy rằng, vùng biển Đông Nam Bộ có tổng sản lượng cao nhất trong cả nước. Trong đó, sản lượng cá nổi lớn cao nhất (khoảng 5.229 tấn trong mùa gió đông bắc và 6.888 tấn trong mùa gió tây nam). Tuy nhiên, xét trong cả nước, cá nổi nhỏ là nhóm loài có tổng sản lượng cao nhất với tổng sản lượng khoảng 10.970 tấn trong mùa gió đông bắc và 13.997 tấn trong mùa gió tây nam (Bảng 2). Việc nghiên cứu dự báo nguồn lợi hải sản sẽ giúp ngư dân tiết kiệm được chi phí xăng dầu và thời gian tìm kiếm ngư trường và nâng cao hiệu quả khai thác đã và đang được các cơ quan chức năng thực hiện. Tuy nhiên, việc tăng cường cơ sở khoa học nhằm nâng cao hiệu quả các bản dự báo ngư trường khai thác hải sản cho các nhóm loài, các loài hiện nay vẫn đang cần được thúc đẩy nhiều hơn nữa. Với mục tiêu đó, kết quả nghiên cứu front nhiệt biển ở trên có thể áp dụng trong xác đinh các ngư trường tiềm năng, đây cũng là một kênh thông tin tham khảo có ý nghĩa quan trọng trong việc xây dựng và phát hành các bản dự báo ngư trường hiện nay.

Kết quả phân tích các bản đồ phân bố ngư trường khai thác hải sản và bản đồ phân bố front nhiệt biển trong hai mùa gió đông bắc và tây nam cho thấy, những khu vực có sản lượng cao thường tập trung gần nơi xuất hiện các dải front nhiệt, cụ thể ở vịnh Bắc Bộ, sản lượng khai thác cá cao (tổng sản lượng ô lưới trên 50,0 tấn) tập trung dọc theo khu vực có sải độ sâu từ 30-50 m nước từ khu vực đảo Bạch Long Vĩ đến khu vực biển Nghệ An-Hà Tĩnh. Ở khu vực Nam Trung Bộ, khu vực có sản lượng cao là khu vực biển Ninh Thuận-Bình Thuận và ở vùng biển Tây Nam Bộ, khu vực có sản lượng cao là khu vực ngoài khơi vùng biển Cà Mau. Ngư trường khai thác hầu ít thấy sự biến đổi giữa hai mùa gió đông bắc và mùa gió tây nam nhưng có sự thay rõ về vị trí các khu vực có sản lượng cao; Những khu vực này thường ở gần khu vực xuất hiện front hoặc nơi có gradient nhiệt độ $\geq 0,05^{\circ} \mathrm{C} / 10 \mathrm{~km}$ (Hình 6).

Tuy nhiên, ở vùng biển xa bờ miền Trung và quần đảo Hoàng Sa sản lượng cá khai thác thấp hơn (tổng sản lượng ô lưới < 10,0 tấn) mặc dù khu vực này cũng thấy xuất hiện dải front song song với đường bờ. Xem xét đến yếu tố địa hình thấy rằng, khu vực này này có địa hình đáy biển dốc, tốc độ dòng chảy cao đặc biệt là trong mùa gió đông bắc (hoàn lưu gió mùa đông bắc áp sát bờ Trung Bộ Việt Nam với cường độ cực đại có tể đạt $60-70 \mathrm{~cm} / \mathrm{s}$ [12]) nên ảnh hưởng rất lớn đến kĩ thuật khai thác của các nghề như nghề rê, vây hay nghề chụp mực...do vậy, sản lượng khai thác cá các nghề trên thường thấp. 
Tạp chi Khí tương Thủy văn 2020, 719, 66-75; doi:10.36335/VNJHM.2020(719).66-75

Bảng 2. Sản lượng (SL) khai thác các nhóm nguồn lợi hải sản ở các vùng biển Việt Nam trong năm 2017-2018.

\begin{tabular}{|c|c|c|c|c|c|c|c|c|c|c|}
\hline \multirow[t]{2}{*}{ Mùa } & \multirow[t]{2}{*}{ Nhóm loài } & \multicolumn{2}{|c|}{ Vịnh Bắc Bộ } & \multicolumn{2}{|c|}{$\begin{array}{c}\text { Miền Trung } \\
\text { và xa bờ }\end{array}$} & \multicolumn{2}{|c|}{ Đông Nam Bộ } & \multicolumn{2}{|c|}{ Tây Nam Bộ } & \multirow{2}{*}{$\begin{array}{c}\text { Tổng } \\
\text { SLL } \\
\text { (tấn) }\end{array}$} \\
\hline & & $\begin{array}{c}\text { Tổng } \\
\text { SL } \\
\text { (tấn) }\end{array}$ & $\begin{array}{c}\text { Trung } \\
\text { bình } \\
\text { SL } \\
(\mathrm{kg})\end{array}$ & $\begin{array}{c}\text { Tổng } \\
\text { SL } \\
\text { (tấn) }\end{array}$ & $\begin{array}{c}\text { Trung } \\
\text { bình } \\
\text { SL } \\
(\mathrm{kg})\end{array}$ & $\begin{array}{c}\text { Tổng } \\
\text { SL } \\
\text { (tấn) }\end{array}$ & $\begin{array}{c}\text { Trung } \\
\text { bình } \\
\mathrm{SL} \\
(\mathrm{kg})\end{array}$ & $\begin{array}{c}\text { Tổng } \\
\text { SL } \\
\text { (tấn) }\end{array}$ & $\begin{array}{c}\text { Trung } \\
\text { bình } \\
\text { SL } \\
(\mathrm{kg})\end{array}$ & \\
\hline \multirow{6}{*}{$\begin{array}{l}\text { Mùa gió } \\
\text { đông bắc }\end{array}$} & Cá đáy & 62 & 48,7 & 60 & 48,3 & 43 & 30,4 & 393 & 35,5 & 558 \\
\hline & Cá nổi lớn & 491 & 150,2 & 2765 & 254,7 & 5229 & 292,8 & 785 & 91,0 & 9269 \\
\hline & Cá nổi nhỏ & 3295 & 203,6 & 1674 & 308,6 & 4414 & 254,1 & 1586 & 256,7 & 10970 \\
\hline & Cá rạn & 4 & 33,7 & 57 & 33,7 & 138 & 39,6 & 175 & 31,8 & 373 \\
\hline & Chân đầu & 206 & 42,2 & 52 & 17,1 & 42 & 8,1 & 114 & 14,8 & 414 \\
\hline & Nhóm khác & 731 & 141,4 & 215 & 88,5 & 293 & 67,1 & 139 & 39,9 & 1377 \\
\hline \multicolumn{2}{|c|}{ Tổng SL mùa gió đông bắc } & 4789 & & 4823 & & 10158 & & 3192 & & \\
\hline \multirow{6}{*}{$\begin{array}{l}\text { Mùa gió } \\
\text { tây nam }\end{array}$} & Cá đáy & 62 & 95,8 & 119 & 206,1 & 31 & 53,2 & 393 & 38,1 & 605 \\
\hline & Cá nổi lớn & 824 & 150,3 & 2003 & 235,9 & 6888 & 348,9 & 340 & 60,0 & 10056 \\
\hline & Cá nổi nhỏ & 3960 & 282,1 & 3641 & 508,6 & 5749 & 390,3 & 647 & 139,7 & 13997 \\
\hline & Cá rạn & 5 & 49,3 & 62 & 36,6 & 157 & 57,3 & 204 & 33,4 & 428 \\
\hline & Chân đầu & 282 & 62,1 & 177 & 40,1 & 51 & 12,1 & 114 & 24,4 & 624 \\
\hline & Nhóm khác & 871 & 180,6 & 175 & 49,3 & 380 & 92,9 & 57 & 65,1 & 1483 \\
\hline \multicolumn{2}{|c|}{ Tổng SL mùa gió tây nam } & 6005 & & 6177 & & 13256 & & 1755 & & 27194 \\
\hline
\end{tabular}

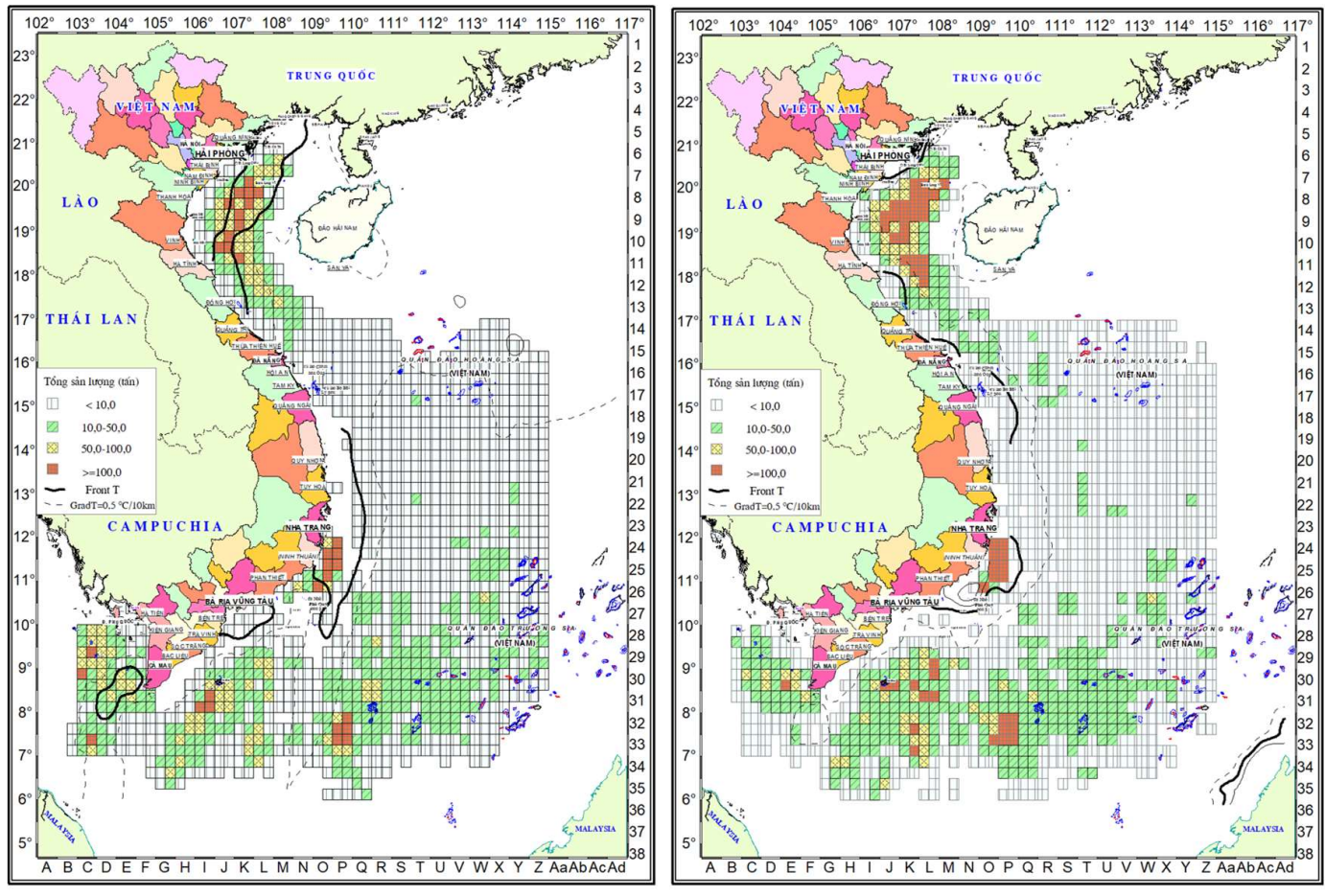

Hình 6. Phân bố tổng sản lượng khai thác cá theo ô lưới ( 0,25 độ kinh vĩ) và fornt nhiệt độ trong mùa gió đông bắc (hình trái) và mùa gió tây nam (hình phải).

\section{Kết luận}

Sự xuất hiện của các dải front nhiệt phụ thuộc vào sự hoạt động của hệ thống gió mùa đông bắc và tây nam:

Mùa gió đông bắc: Trên toàn vùng biển Việt Nam hình thành ba dải front nhiệt độ chính ở vịnh Bắc Bộ, Nam Trung Bộ và cửa vịnh Thái Lan. 
Mùa gió tây nam: xuất hiện hai dạng front là front vùng cửa sông ven bờ nơi giao nhau giữa khối nước mặn lợ với nước thềm lục địa và front vùng ngoại vi các trung tâm hoạt động của nước trồi.

Sản lượng cá khai thác cao thường tập trung ở khu vực gần các dải fornt này hoặc gần khu vực có gradien nhiệt độ $\geq 0,05 \%$ \% $10 \mathrm{~km}$ ở vùng biển vịnh Bắc Bộ, Nam Trung Bộ và Tây Nam Bộ.

Đóng góp của tác giả: Xây dựng nghiên cứu ý tưởng: N.V.H., N.H.M., B.T.H.; Lựa chọn phương pháp nghiên cứu: N.V.H., N.H.M.; Xử lý số liêu: N.V.H., B.T.H., T.V.V., C.T.V.; Viết bản thảo N.V.H., N.H.M., B.T.H.; Chỉnh sửa báo cáo: N.V.H., N.H.M., C.T.V.

Lời cảm ơn: Kết quả nghiên cứu này được hỗ trợ bởi Dự án "Điều tra Ngư trường” giai đoạn 2017-2020; Đề tài "Nghiên cứu dự báo ngư trường khai thác nguồn lợi cá nổi nhỏ ở biển Việt Nam”, mã số KC.09.19/16-20 thuộc Chương trình khoa học và công nghệ cấp quốc gia giai đoạn 2016-2020.

Lời cam đoan: Tập thể tác giả cam đoan bài báo này là công trình nghiên cứu của tập thể tác giả, chưa được công bố ở đâu, không được sao chép từ những nghiên cứu trước đây; không có sự tranh chấp lợi ích trong nhóm tác giả.

\section{Tài liệu tham khảo}

1. Cornillon, P. SST fronts of the Pacific coastal and marginal seas. Pac. Oceanogr. 2003, 1 , 90-113.

2. Wang, D.; Liu, Y.; Qi, Y.; Shi, P. Seasonal variability of thermal fronts in the northern South China Sea from satellite data. Geophys. Res. Lett. 2001, 28, 3963-3966. https://doi.org/10.1029/2001GL013306.

3. Bakun, A. Fronts and eddies as key structures in the habitat of marine fish larvae: Opportunity, adaptive response and competitive advantage. Sci. Marina 2006, 70, 105-122.

4. Belkin, I.M.; Cornillon, P.C.; Sherman, K. Fronts in large marine ecosystems. Prog. Oceanogr. 2009, 81, 22, 3-236. https://doi.org/10.1016/j.pocean.2009.04.015.

5. Belkin, I.M.; Cornillon, P.C.; Sherman, K. Fronts in the World Ocean's Large Marine Ecosystems. International Council for the Exploration Theme Session D: Comparative Marine Ecosystem of the Sea (ICES), 2007, 21, pp. 33.

6. Bộ, Đ.N.V. Báo cáo tổng kết khoa học kỹ thuật đề tài KC.09.14/06-10 "Ứng dụng và hoàn thiện quy trình công nghệ dự báo ngư trường phục vụ khai thác hải sản xa bờ", Cục Thông tin khoa học và Công nghệ Quốc gia: Hà Nội, 2010.

7. Tố, L.Đ., Báo cáo tổng kết đề tài "Luận chứng khoa học cho việc dự báo biến động số lượng và phân bố nguồn lợi cá", Chương trình Nghiên cứu biển cấp Nhà nước, 1995.

8. Cayula, J.F.; Cornillon, P. Multi-Image Edge Detection for SST Images. J. Atmos. Oceanic Technol. 1995, 12, 173-191.

9. Chang, Y., et al., Fine-scale sea surface temperature fronts in wintertime in the northern South China Sea. Int. J. Remote Sens. 2010, 31, 4807-4818.

10. Ullman, D.; Cornillon, P. Evaluation of Front Detection Methods for Satellite-Derived SST Data Using In Situ Observations. J. Atmos. Oceanic Technol. 2000, 17, 1667-1675.

11. Sản, B.T. Nguồn lợi Thủy sản Việt Nam. Nhà xuất bản Nông nghiệp Hà Nội, 1996, pp. 616.

12. Nghĩa, N.V.; Hà, V.V. Trữ lượng và phân bố của một số nhóm nguồn lợi ở biển Việt Nam giai đoạn 2011-2015. Nhà xuất bản Nông nghiệp (Tuyển tập các công trình nghiên cứu tiêu biểu giai đoạn 2011-2015, Bộ Nông nghiệp và Phát triển Nông thôn), 2017.

13. Scripps Institution of Oceanography. Scientific result of Marine investigation of the Sounth China Sea and Gulf of Thailand 1959-1961. La Jolla, CA: University of California, Scripps Institution of Oceanography, 1961, pp. 198.

14. Tố, L.Đ. Hải Dương Học Biển Đông. Nhà xuất bản đại học quốc gia Hà Nội, 1999. 


\title{
Study on sea surface temperateture front distribution in Viet Nam waters for forcast of fishing ground
}

\section{Nguyen Van Huong ${ }^{*}$, Nguyen Hoang Minh ${ }^{1}$, Bui Thanh Hung ${ }^{1}$, Tran Van Vu${ }^{1}$, Can Thu $\operatorname{Van}^{2}$}

${ }^{1}$ Reseach institute for marine fisheres; nvhuong0509@gmail.com; nhminh10@gmail.com; bthungrimf@gmail.com; vurimf@gmail.com

${ }^{2}$ HCM city University of Natural Resources and Environment; ctvan@hcmunre.edu.vn

\begin{abstract}
The formation of sea surface temperature (SST) front in Bien Dong sea depends on the operation of the northeast and southwest monsoon systems. During the northeast monsoon season, the Gulf of Tonkin exists a SST front running parallel to the $50 \mathrm{~m}$ isometric line, strongest in the area near Bach Long Vi island to coastal waters of Deo Ngang-Quang Binh provine. The SST gradient in this area is greater than $0.2{ }^{\circ} \mathrm{C} / 10 \mathrm{~km}$. In the South Central Coast, there is a front located off the central coast along the meridian $110,0^{\circ} \mathrm{E}$ from the marine area of Da Nang province to Phu Quy island and in the of the Gulf of Thailand forming a SST front in the offshore area waters of $\mathrm{Ca}$ Mau province. In the southwest monsoon season, in the periphery of the South Central upturned water activity center, there exists a front extending from the waters of north of Vung Tau to Khanh Hoa provine with a great horizontal gradient of temperature and salinity. In addition, in the northern of the central area of the upwelling in the near coast of Deo Ngang-Quang Binh province is overlapping strip of brackish water mass ( $\mathrm{T}$ $=28,0-31,0{ }^{\circ} \mathrm{C}, \mathrm{S}<33,0 \%$ ) in the coastal West bank of the Gulf of Tonkin and offshore waters with low temperature, relatively high salinity $\left(\mathrm{T}=27,0-28,0^{\circ} \mathrm{C}, \mathrm{S}=33,0-34,0 \%\right.$ ). The results of research on fishing grounds show that areas with high catches are usually concentrated in areas near these fornts or near areas with SST gradient $\geq 0,05^{\circ} / 10 \mathrm{~km}$.
\end{abstract}

Keywords: Front; Gradien temperature; Fishing grounds. 